Indonesian Aquaculture Journal, 15 (2), 2020, 59-65

Available online at: http://ejournal-balitbang.kkp.go.id/index.php/iaj

\title{
REPRODUCTIVE PERFORMANCE OF HATCHERY-BRED, WILD-CAUGHT BROODSTOCK, AND THEIR OUTBREED OF THE AFRICAN CATFISH Clarias gariepinus (Burchell, 1822)
}

\author{
Victor Oscar Eyo\#, Felix Eze, and Ochuko Joshua Eriegha \\ *) Department of Fisheries and Aquaculture, Faculty of Marine Environmental Management \\ Nigeria Maritime University, Okerenkoko, P. M. B. 1005, Delta State, Nigeria
}

(Received: April 2, 2020; Final revised: October 21, 2020; Accepted: October 24, 2020)

\begin{abstract}
This study was conducted to evaluate the reproductive performance of hatchery-bred and wild-caught broodstock of Clarias gariepinus. Thirty pairs of each hatchery-bred and wild-caught broodstock (15 females and 15 males) was used for the study. Induced breeding was carried out in four groups with three replications at a ratio of 1:1 by hypophysation method. Group A: hatchery-bred male and hatchery-bred female (HBM m + HBF f); B: wild-caught male and wild-caught female (WCM m+ WCF f), C: hatchery-bred female and wild-caught male (HBF $\mathrm{f}+\mathrm{WCM}$ m and $\mathrm{D}$ : wild-caught female and hatchery-bred male $\mathrm{C}$. gariepinus (WCF $\mathrm{f}+\mathrm{HBM}$ m. Results showed that egg diameter, sperm motility, sperm density, and male GSI were not significantly different $(P>0.05$ ) whereas ovary weight, sperm volume, fecundity, female GSI, and percentage fertilization were significantly higher $(P<0.05)$ in hatchery-bred broodstock than wildcaught broodstock. Hatchability was significantly higher $(P<0.05)$ in Group $C$ and $D$ than A and $B$. In conclusion, a better reproductive performance in $\mathrm{C}$. gariepinus with an economic advantage could be recorded through the combination of wild-caught and hatchery-bred broodstock.
\end{abstract}

\section{KEYWORDS: fecundity; gonadosomatic index; ovary weight; hatchability; fertilization rate;} outbreeding

\section{INTRODUCTION}

Predictions from World Bank (2014) reveals that by 2030 , aquaculture will supply about $62 \%$ of food fish globally. The future scenarios of fish supplydemand indicate the need to double fish production effort to meet growing global demand (World Bank, 2014). In Africa, the contribution of aquaculture production to the global total aquaculture production is only $2 \%$ with Egypt being the highest producer followed by Nigeria (FAO, 2017). The future of aquaculture in Nigeria is very promising most especially with natural conditions favoring aquaculture production such as optimal temperature and abundant water resources of good quality. The African Catfish Clarias gariepinus which is a member of the popular family Clariidae is the most preferable and successful aqua-culture species in Nigeria. It is highly rich in

\footnotetext{
\# Correspondence: Department of Fisheries and Aquaculture, Faculty of Marine Environmental Management. Nigeria Maritime University, Okerenkoko, P. M. B. 1005, Delta State, Nigeria

Tel. +2348065162221

E-mail: sirvick2003@yahoo.com; victor.eyo@nmu.edu.ng
}

nutrients such as omega-3-fatty acid, thiamine, iron, riboflavin, vitamins $A$, vitamin $D$, calcium, and phosphorus which are required for good health and tissue development (Awom \& Eyo, 2016). In Nigeria, some fish consumers give preference to $C$. gariepinus because of its organoleptic characteristics including nice taste and high meat quality after different processing and preparation methods such as smoking, barbecue, frying, oven-drying, etc. (Ekanem et al., 2012). Also, C. gariepinus exhibits several biological attributes such as hardiness, disease resistance, fast growth rate, attractive market size, high stocking densities, tolerance of poor of environmental parameters, acceptance of artificial feed, and high market value (Arong \& Eyo, 2017; Awom \& Eyo, 2016; Eyo et al., 2014). Apart from these attributes, C. gariepinus also exhibits some favorable reproductive characteristics such as ease of induced breeding, high fecundity, fast gonadal development in captivity. In new aquaculture species and many cultured fishes, variable and unpredictable reproductive performance is a crucial factor limiting the successful mass production of juveniles (Izquierdo 
et al., 2001) and fecundity is a crucial criterion during species selection for aquaculture purpose (Mayer et al., 1989). The percentage of the fish body weight could be used to determine eggs production by the gonadosomatic index (Amtyaz et al., 2013). In fishes, gonadosomatic index indicates the ratio of the gonad size relative to fish size and is also a good indicator of gonadal development. Gonadal development involves series of interrelated phases with each phase requiring precise control and coordination and for viable gametes to be produced for survival of young fish at the optimum time of the year (Chattopadhyay $\&$ Chattoraj, 2017). In fisheries science, egg quality is the combination of various characteristics which contribute to the successful fertilization, incubation, hatching, and larval survival of fish (Hicks et al., 2015). Lack of high-quality fish seeds produced from healthy broodstock is a major challenge that limits fish production in Nigeria which consequently results in low profitability or loss of money (Eyo \& Akanse, 2018). As observed by Phleps (2010), three issues namely management of broodstock, induced spawning and larval rearing has contributed immensely to the global progression in hatchery management. Most times, several farms refuse to sell their matured and ripe broodstock to hatchery owners and fish breeders while some farms sell their broodstock at very high rates. According to Eyo \& Akanse (2018), cost of hatchery conditioned broodfish of $\mathrm{C}$. gariepinus is about $\mathrm{N} 4000.00 / \mathrm{kg}$ (USD11.11) or even costlier based on the locality. Consequently, some fish breeders who cannot afford hatchery conditioned broodstock have no other option than to search for alternative and cheaper sources of broodstock such as collection of wild broodstock. Eyo et al. (2013) noted that collection of wild C. gariepinus has been seen by some farmers as a cheaper alternative to hatchery-bred fish. However, there is paucity of information on the comparative reproductive performance of $C$. gariepinus broodstock obtained from the wild and hatchery. This study therefore aims at evaluating the reproductive performance of hatchery raised and wild-caught broodstock of C. gariepinus.

\section{MATERIALS AND METHODS}

\section{Selection, Collection, Acclimatization, and Conditioning of Wild-Caught and Hatchery- Bred Broodfish}

A total of 30 wild-caught $C$. gariepinus broodstock (15 females and 15 males) with body weight range of $1.5-2.0 \mathrm{~kg}$, and total length ranged from $51.41-52.20$ $\mathrm{cm}$ were bought from landings of artisanal fishers in Ayadehe, Itu Head Bridge $\left(5^{\circ} 14^{\prime} 30^{\prime \prime} \mathrm{N}, 8^{\circ} 6^{\prime} \mathrm{O}^{\prime \prime} \mathrm{E}\right)$ between June and July 2017. Before collection, the male and female broodstocks were selected according to criteria given by de Graaf \& Janssen (1996). For the selection of female broodstock, a swollen and distended abdomen from which ripe uniform eggs obtained by slightly pressing the abdomen was used. A reddish and protruded genital papilla was used as the selection criteria for male broodstock. The collected broodstocks were transported immediately to a private hatchery in Uyo, Akwa Ibom State for acclimatization and conditioning. The fish were sexed and kept in six tarpaulin tank measuring $1 \mathrm{~m} \times 1 \mathrm{~m} \times 1 \mathrm{~m}$ (5 fish per tank). The tanks were labeled $A_{1}, A_{2}, A_{3}, B_{1}, B_{2}, B_{3}$. Randomly female fish were conditioned in tank $A_{1}$, $A_{2}, A_{3}$ and male fish were $B_{1}, B_{2}, B_{3}$. For hatchery broodstock, a total of 30 healthy $C$. gariepinus broodstock ( 15 females and 15 males) were collected from a private hatchery in Uyo, Akwa Ibom State. The male and female hatchery broodstocks with a body weight range of $1.5 \pm 0.5 \mathrm{~kg}$ were 18 months old. The fish were sexed and also kept in six tarpaulin tank measuring $1 \mathrm{~m} \times 1 \mathrm{~m} \times 1 \mathrm{~m}$ (five fish per tank). The tanks were labeled $C_{1}, C_{2}, C_{3^{\prime}} D_{1}, D_{2}, D_{3}$. Female fish were condition in tank $\mathrm{C}_{1}, \mathrm{C}_{2}, \mathrm{C}_{3}$ and male fish were $D_{1}, D_{2}, D_{3}$. Water quality in all the broodstock tanks was managed by regular changing of water and the fish were fed twice daily with $13 \mathrm{~mm}$ of Coppens fish feed at $2 \%$ of the body weight for 14 days. All the broodstock were kept under natural photoperiod conditions (12 hours light, 12 hours dark).

\section{Breeding Experiment of Experimental Fish}

After acclimatization and conditioning of the hatchery-bred and wild-caught broodfish, four groups of breeding were carried out. Group A breeding was carried out using hatchery-bred male and hatcherybred female $\mathrm{C}$. gariepinus (HBM m+ HBF f), Group B breeding was carried out using wild-caught male and wild-caught female $\mathrm{C}$. gariepinus (WCM $\mathrm{m}+$ WCF $\mathrm{f}$ ), Group $\mathrm{C}$ breeding was carried out with hatchery-bred female and wild-caught male $C$. gariepinus (HBF $f+$ WCM $\mathrm{m}$ ) whereas Group D breeding was carried out using wild-caught female and hatchery-bred male $C$. gariepinus (WCF f + HBM m). In each breeding group, seven pairs of male and female broodstock were used in a ratio of 1:1. Induced breeding was carried out by hypophysation method (Ayinla, 1998). Artificial spawning substrate (nylon mosquito nets) was placed in the incubator $(100 \mathrm{~cm} \times 100 \mathrm{~cm} \times 80 \mathrm{~cm})$ containing clean and aerated water of $85 \mathrm{~cm}$ in depth with a flow-through setup. Eggs from each experimental group were fertilized by mixing the stripped eggs with milt obtained from the corresponding male fish in the group. Thereafter, the fertilized eggs were immediately incubated by spreading them thinly on the artificial spawning substrate placed in the incuba- 
tor and allowed to incubate for a period of 24-36 hours before hatching commenced. After hatching, the newly hatched larvae were allowed to feed on its yolk sac (endogenous feeding) for three days. On the fourth day of hatching, the fry was exposed to their first exogenous feeding by administering Artemia for a period of 10 days. Thereafter, the fry was fed with $0.1 \mathrm{~mm}$ Coppens feed ad libitum thrice daily. The number of eggs (\% stripped, number of egg fertilized $(\%$, and number of egg hatched (\%) was calculated as follows:

Ovary weight $(\mathrm{g})=$ unstripped fish weight $(\mathrm{g})$ stripped fish weight $(\mathrm{g})$ of fish after stripping Number of eggs stripped (incubated) $=$ Unstripped fish weight ( $g$ ) - Stripped fish weght ( $g$ ) $x$ No. of eggs per gram of ovary mass

Number of eggs fertilized $=$ No. of incubated eggs No. of opaque eggs (dead eggs)

Percentage of eggs fertilized $(\%)=$ $\frac{\text { No. of incubated eggs - No. of opaque eggs }}{\text { Tota No. of incubated eggs }} \times 100$ Total No. of incubated eggs

Number of eggs hatched $=$ No . of fertilized eggs No. of unhaatched eggs

Egg hatchability $(\%)=$ $\underline{\text { No. of whitish broken eggs }} \times 100$

No. of fertilized egg

\section{Gonadosomatic Index of Hatchery-Bred and Wild-Caught Broodstock}

Biometric parameters such as total length (TL$\mathrm{cm})$, total weight (TW-g), and gonad weight (GW - g) were measured and recorded for each broodfish. The length and weight of the fish were measured to the nearest $0.1 \mathrm{~cm}$ and $0.1 \mathrm{~g}$ with the aid measuring board and $M$ etlar-5000D electronic weighing balance respectively. Gonado somatic index (GSI) was calculated according to the equation given by (Bolger $\&$ Connolly, 1989) as follows:

$$
\text { GSI }\left(\%=\frac{\text { Gonad weight of fish }(\mathrm{g})}{\text { Fish body weight }(\mathrm{g})} \times 100\right.
$$

\section{Gonad Gross Morphology of Hatchery-Bred and Wild-Caught Broodstock}

The female ovary and male testis of broodfish collected from the wild and hatchery were subjected to histological analysis. The gonadal tissues were fixed in Bouin's fluid for 48 hours, manually processed based on the standard method and sectioned at $10 \mu$ with a rotary microtome, before dewaxed in xylene, before staining with haematoxylin and eosin for mi- croscopic examinations according to (Bancroft \& Cook, 1994).

\section{Determination of Egg Quality of Hatchery- Bred and Wild-Caught Broodstock}

Egg quality of broodstock from the wild and hatchery was evaluated following methods of Adewumi et al. (2005) using egg diameter. Thirty fresh eggs were collected from each fish and measured using an ocular eye piece from a stereo microscope in millimeter $(\mathrm{mm})$. For eggs with pear-shaped structure, the diameters of short and long axes were measured and the mean diameter was recorded as the oocyte diameter.

\section{Determination of Sperm Quality of Hatchery- Bred and Wild-Caught Brood Fish}

The male brood fish were sacrificed before dissecting to remove the matured testes containing the milt. Small incisions were quickly made on the lobes of the testes using a sterile surgical blade to aid milt extraction. The milt was carefully and quickly squeezed out into a clean petri dish before the volume (mL) was measured with a plastic syringe. For sperm motility evaluation, the spermatozoa were activated by quickly adding a drop of distilled water to a drop of milt on a clean glass slide before observing the sperm motility immediately with the aid of MS001 Binocular Microscope (x10). Spermatozoa motility and density were determined following the methods of Adewumi et al. (2005). The absence or presence of spermatozoa motility was expressed as (0) for absent and (1) for present following the scale given by Adewumi et al. (2005). Spermatozoa density was rated on a three level scale of 1, 2, and 3 (representing low, medium, and high density respectively).

\section{Statistical Analysis}

Data obtained from this study were subjected to one way analysis of variance (ANOVA) for significance at $P=0.05$ using PASW windows software (predictive analytical software) program (version 19.0). Effects with a probability of P>0.05 were considered not significant. Least significance difference (LSD) was used for mean separation.

\section{RESULTS AND DISCUSSION}

\section{Mean of Ovary, Fecundity, and Egg Diameter}

Results obtained showed that hatchery-bred female (HBF) of $\mathrm{C}$. gariepinus broodstock had fecundity of $104,953.33 \pm 2,985.89$ eggs (Table 1 ), mean egg diameter ( $1.54 \pm 0.003 \mathrm{~mm})$, mean female body weight of $1,071.87 \pm 13.05 \mathrm{~g}$, mean female total length $(51.76 \pm 0.34 \mathrm{~cm})$, and mean ovary weight 
Reproductive performance of hatchery, wild broodstock, and ..... (Victor Oscar Eyo)

Table 1. Mean of ovary, egg diameter, fecundity, and gonadosomatic index of hatchery-bred and wild-caught broodstock of $\mathrm{C}$. gariepinus

\begin{tabular}{lcc}
\hline \multicolumn{1}{c}{ Body parameters } & Hatchery-bred female & Wild-caught female \\
\hline Mean female body weight $(\mathrm{g})$ & $1,071.87 \pm 13.05^{\mathrm{a}}$ & $1,049.06 \pm 8.37^{\mathrm{b}}$ \\
Mean ovary weight $(\mathrm{g})$ & $149.93 \pm 4.27^{\mathrm{a}}$ & $137.47 \pm 2.75^{\mathrm{b}}$ \\
Mean egg diameter (mm) & $1.54 \pm 0.003^{\mathrm{a}}$ & $1.53 \pm 0.003^{\mathrm{a}}$ \\
Mean fecundity (No. of eggs) & $104,953.33 \pm 2,985.89^{\mathrm{a}}$ & $96,226.67 \pm 1,927.19^{\mathrm{b}}$ \\
\hline
\end{tabular}

Note: * Means with the same superscript are not significantly different $(P>0.05)$

(149.93 $\pm 4.27 \mathrm{~g})$. For wild-caught female (WCF) C. gariepinus, mean fecundity was $96,226.67 \pm 1,927.19$ eggs, mean egg diameter $(1.53 \pm 0.003 \mathrm{~mm})$, mean female body weight $(1,049.06 \pm 8.37 \mathrm{~g})$, mean female total length $(51.67 \pm 0.26 \mathrm{~cm})$ and mean ovary weight $(137.47 \pm 2.75 \mathrm{~g})$.

The mean egg diameter of hatchery-bred and wildcaught broodstock were not significantly different $(P>0.05)$ whereas ovary weight and mean fecundity were significantly higher $(P<0.05)$ in hatchery-bred C. gariepinus broodstock than wild-caught broodstock. Many factors such as nutritional state, fish size, physical condition, age, and reproductive history have been known to influence the fecundity in fish (Izquierdo et al., 2001). According to Watanabe (1990), nutrition affects ovarian development and fecundity. In this study, the significant variation observed in ovary weight and fecundity may be attributed to the nutrition of the broodstock. It is known that nutritional contents such as lipids and proteins are the major energy sources available in vitellus which is utilized for embryogenesis in fish (Evans et al., 1996; Kamler, 2005; Kjørsvik et al., 2003). Hatcherybred broodstock may have been exposed to good and adequate nutrition which could help in improving ovary development than wild-caught broodstock of C. gariepinus. According to Quiñonesarreola et al. (2015), the adequate development of eggs is dependent on the biochemical reserves which are transferred from the female fish to the eggs. Findings of this study indicate that hatchery-bred broodstock of $\mathrm{C}$. gariepinus may have a better biochemical reserve than wild-caught.

\section{Gonadosomatic Index}

Hatchery-bred female had a mean gonadosomatic index (GSI- $\%$ of $13.98 \pm 0.35 \%$ (Table 2). Wild-caught female had a mean gonadosomatic index of $13.08 \pm$ $0.19 \%$ Hatchery-bred male had a mean gonadosomatic index of $0.87 \pm 0.03 \%$ Wild-caught male had a mean gonadosomatic index (GSI) of $0.86 \pm 0.02 \%$ Gonadosomatic index (GSI) is an important tool used in fisheries and aquaculture to evaluate the repro- ductive condition and status of fish (Opeh et al., 2018). In this study, mean ovary weight and GSI of hatchery-bred female were significantly higher $(P<0.05)$ than wild-caught. Mean testis weight and male GSI of broodstock from the hatchery were not significantly different $(P>0.05)$ from the wild-caught broodstock. It indicates that the female broodstocks used in this study were managed and conditioned optimally since GSI was higher than the wild one. In practice female broodstock fed better than male indicated with the GSI obtained whereas there were significant different between female but not significant in male.

\section{Sperm Quality}

The mean sperm quality of hatchery-bred and wildcaught broodstock of $C$. gariepinus is presented in Table 3. Results showed that hatchery-bred male $\mathrm{C}$. gariepinus broodstock with gonad weight of $9.47 \pm$ $0.35 \mathrm{~g}$ had a sperm volume of $4.08 \pm 0.19 \mathrm{~mL}$, sperm motility of $1.00 \pm 0.00 \mathrm{sec}$., and sperm density $(3.00$ \pm 0.00 ). Wild-caught male $C$. gariepinus broodstock had a mean gonad weight of $8.93 \pm 0.21 \mathrm{~g}$, mean sperm volume $(3.72 \pm 0.10 \mathrm{~mL})$, mean sperm motility $(1.00 \pm 0.00 \mathrm{sec}$.) and mean sperm density (3.00 $\pm 0.00)$. The results showed that it was not significantly different $(P>0.05)$ between hatchery and wild male for the weight, volume, and density of sperm as well as motility, even though the body weight was significant different. This indicates that the sperm of C. gariepinus from the two sources have the same quality.

\section{Fertilization and Hatchability Indices}

The fertilization and hatchability indices are presented in Table 4. Group A, B, and D are not significant different $(P<0.05)$ for fertilization rate. But they are significant different with group $C(P<0.05)$. Percentage hatchability in group $A, B$, and $D$ are not significantly different $(P>0.05)$. group $A$ and $B$ are significant $(P<0.05)$ with group $C$ while $C$ and $D$ are not significantly different $(P>0.05)$. This may not be attributed to the variation in the size of the female fish in the experimental groups which was signifi- 
Table 2. Mean gonadosomatic index (GSI-\%) of hatchery-bred and wild-caught broodstock of C. gariepinus

\begin{tabular}{lcc}
\hline \multicolumn{1}{c}{ Body parameters } & Hatchery-bred broodstock (HBB) & Wild-caught broodstock (WCB) \\
\hline Mean female body weight $(g)$ & $1,071.87 \pm 13.05^{\mathrm{a}}$ & $1,049 \pm 8.37^{\mathrm{b}}$ \\
Mean ovary weight $(\mathrm{g})$ & $149.93 \pm 4.27^{\mathrm{a}}$ & $137.47 \pm 2.75^{\mathrm{b}}$ \\
Mean female GSI (\%) & $13.98 \pm 0.35^{\mathrm{a}}$ & $13.08 \pm 0.19^{\mathrm{b}}$ \\
Mean male body weight (g) & $1,081.60 \pm 10.70^{\mathrm{a}}$ & $1,025.27 \pm 7.31^{\mathrm{b}}$ \\
Mean testis weight (g) & $9.47 \pm 0.35^{\mathrm{a}}$ & $8.93 \pm 0.21^{\mathrm{a}}$ \\
Mean male GSI (\%) & $0.87 \pm 0.03^{\mathrm{a}}$ & $0.86 \pm 0.02^{\mathrm{a}}$ \\
\hline
\end{tabular}

Note: * Means with the same superscript are not significantly different $(P>0.05)$

Table 3. Mean sperm quality of hatchery-bred and wild-caught broodstock of $\mathrm{C}$. gariepinus

\begin{tabular}{lcc}
\hline \multicolumn{1}{c}{ Body parameters } & Hatchery broodstock & Wild broodstock \\
\hline Mean sperm volume $(\mathrm{mL})$ & $4.08 \pm 0.19^{\mathrm{a}}$ & $3.72 \pm 0.10^{\mathrm{b}}$ \\
Mean sperm motility $(\mathrm{sec})$. & $1.00 \pm 0.00^{\mathrm{a}}$ & $1.00 \pm 0.00^{\mathrm{a}}$ \\
Mean sperm density & $3.00 \pm 0.00^{\mathrm{a}}$ & $3.00 \pm 0.00^{\mathrm{a}}$ \\
\hline
\end{tabular}

Note: * Means with the same superscript are not significantly different $(P>0.05)$

cantly different $(P<0.05)$. The size of the female brood fish is known to influence breeding success in many ways such as egg number and size and juvenile size (Heinimaa \& Heinimaa, 2004). There are observations of the positive effect of female size on alevin's yolk reserves and egg dry weight (Beacham \& Murray, 1985; Ojanguren et al., 1996; Shearer et al., 1994) also noted that large females have higher body-energy reserves to be used during vitellogenesis of eggs compared to smaller female fishes. The result of fertilization rate and hatchability are strongly indicated heterosis effect from outbreeding between hatchery-bred and wild-caught broodstock used in the present study. Results for mean physicochemical parameters of the experimental incubators which were managed at optimal levels are presented in Table 5.

Table 4. Mean hatchability indices of hatchery-bred and wild-caught broodstock of C. gariepinus

\begin{tabular}{|c|c|c|c|c|}
\hline Indices & HBM $\left({ }^{\lambda}\right) \times$ X HBF ( $(+)$ & WCM (ठ) x WCF ( & HBF $(+)$ x WCM $\left({ }^{\lambda}\right)$ & HBM $(\hat{\prime})+$ WCF $(+)$ \\
\hline Mean total length $(\mathrm{cm})$ & $50.89 \pm 0.38^{a}$ & $51.50 \pm 0.39^{a}$ & $52.56 \pm 0.45^{b}$ & $52.09 \pm 0.35^{\mathrm{ab}}$ \\
\hline Unstripped weight (g) & $1,045.00 \pm 12.11^{a}$ & $10,46.57 \pm 12.78^{\mathrm{a}}$ & $1,099.43 \pm 21.39^{b}$ & $1,057.29 \pm 12.50^{b}$ \\
\hline Stripped weight $(\mathrm{g})$ & $902.86 \pm 10.79^{a}$ & $906.00 \pm 9.87^{a}$ & $943.14 \pm 19.69^{b}$ & $921.00 \pm 9.17^{a}$ \\
\hline Mean ovary weight $(\mathrm{g})$ & $142.14 \pm 8.19^{\mathrm{a}}$ & $140.57 \pm 3.68^{a}$ & $156.29 \pm 2.17^{b}$ & $136.28 \pm 4.26^{\mathrm{a}}$ \\
\hline Mean no. of & $99,500.00 \pm$ & $98,400.00 \pm$ & $109,400.00 \pm$ & $95,400.00 \pm$ \\
\hline egg incubated & $5,730.62^{\mathrm{a}}$ & $2578.11^{a}$ & $1,517.67^{b}$ & $2,984.40^{a}$ \\
\hline Mean no. of & $97,201.57 \pm$ & $96,223.43 \pm$ & $108,494.14 \pm$ & $94,526.71 \pm$ \\
\hline egg fertilized & $5663.13^{\mathrm{a}}$ & $2620.74^{a}$ & $1,533.21^{b}$ & $2,958.23^{a}$ \\
\hline $\begin{array}{l}\text { Percentage no. of } \\
\text { egg fertilized }\end{array}$ & $97.66 \pm 0.17^{a}$ & $97.77 \pm 0.12^{a}$ & $99.17 \pm 0.03^{c}$ & $99.08 \pm 0.03^{b}$ \\
\hline No. of eggs hatched & $\begin{array}{c}96,119.29 \pm \\
5635.60^{a}\end{array}$ & $\begin{array}{c}94,956.57 \pm \\
2657.16^{a}\end{array}$ & $\begin{array}{c}107,533.14 \pm \\
1,534.00^{b}\end{array}$ & $\begin{array}{c}93636.14 \pm \\
2953.97^{\mathrm{a}}\end{array}$ \\
\hline Hatchability $(\%)$ & $98.87 \pm 0.20^{\mathrm{a}}$ & $98.67 \pm 0.22^{\mathrm{a}}$ & $99.11 \pm 0.03^{b}$ & $99.05 \pm 0.04^{\mathrm{ab}}$ \\
\hline
\end{tabular}

Note: * Means with the same superscript are not significantly different $(P>0.05)$ 
Reproductive performance of hatchery, wild broodstock, and ..... (Victor Oscar Eyo)

Table 5. Mean physicochemical parameters of the experimental incubator

\begin{tabular}{lcccc}
\hline \multirow{2}{*}{ Parameters } & \multicolumn{5}{c}{ Group incubator } \\
\cline { 2 - 5 } & A & B & C & D \\
\hline pH & $6.96 \pm 0.02$ & $6.95 \pm 0.01$ & $6.98 \pm 0.02$ & $6.97 \pm 0.03$ \\
Dissolved oxygen $(\mathrm{mg} / \mathrm{L})$ & $5.01 \pm 0.05$ & $5.00 \pm 0.02$ & $5.03 \pm 0.02$ & $5.02 \pm 0.04$ \\
Water temperature $\left({ }^{\circ} \mathrm{C}\right)$ & $29.5 \pm 0.01$ & $29.5 \pm 0.01$ & $29.6 \pm 0.02$ & $29.4 \pm 0.03$ \\
Ammonia $(\mathrm{mg} / \mathrm{L})$ & $0.00 \pm 0.00$ & $0.00 \pm 0.00$ & $0.00 \pm 0.00$ & $0.00 \pm 0.00$ \\
\hline
\end{tabular}

\section{CONCLUSION}

In conclusion, the reproductive performance of male and female C. gariepinus broodfish from the same source was lower than the combination of broodstock from the wild and hatchery. In conclusion, a better reproductive performance in $\mathrm{C}$. gariepinus with an economic advantage could be recorded through the combination of wild-caught and hatchery-bred broodstock.

\section{REFERENCES}

Adewumi, A.A., Olaleye, V.F., \& Adesulu, E.A. (2005). Egg and sperm quality of the African catfish, Clarias gariepinus (Burchell) broodstock fed differently heated soybean-based diets. Research Journal of Agriculture and Biological Sciences, 1(1), 17-22.

Amtyaz, M., Atiqullah Khan, M.Z.K., \& M.U.A.H. (2013). Studies on gonadosomatic index $\&$ stages of gonadal development of striped piggy fish, Pomadasys stridens (Forsskal, 1775) (Family; Pomadasyidae) of Karachi Coast, Pakistan. Journal of Entomology and Zoology Studies, 1(0092), 28-31.

Arong, G. \& Eyo, V.O. (2017). Evaluation of house fly (Musca domestica) maggot meal and termite (Macrotermes subhyalinus) meal as supplementary feed for African catfish Clarias gariepinus (Burchell , 1822). International Journal of Entomology and Nematology, 3(1), 42-50.

Awom, I.E. \& Eyo, V.O. (2016). Comparative study of growth performance, food utilization and survival of the African Catfish Clarias gariepinus (Burchell, 1822) fingerlings fed live maggot (Musca domestica) and coppens commercial feed. IJSRSET, 2(2), 379-386.

Ayinla, O.A. (1998). Nutritive and reproductive performance of Clarias gariepinus (Burchell 1822). Ph.D Thesis. University of Ibadan, Nigeria.

Bancroft, J.D. \& Cook, H.C. (1994). Manual of histopathological techniques and their diagnosticapplication. London: Churchill Livingstone.
Beacham, T.D. \& Murray, C.B. (1985). Effect of female size, egg size and water temperature on development biology of Chum salmon (Oncorhynchus keta) from the Nitinat River, British Columbia. Canadian Journal of Fisheries and Aquatic Science, 42, 1755-1765.

Bolger, J. \& Connolly, P.L. (1989). The selection of suitable indices for the measurement and analysis of fish condition. Journal of Fish Biology, 34, 171-182.

Chattopadhyay, N.R. \& Chattoraj, S. (2017). A review on the reproduction and development in fish, $\mathrm{BIO}$ MEDICAL, Journal of Scientific and Technical Research, 1(6), 1747-1751. https://doi.org/10.26717/ BJSTR.2017.01.000529.

de Graaf, G.J. \& Janssen, J.A.L. (1996). Artificial reproduction and pond rearing of the African catfish, Clarias gariepinus in sub-Saharan Africa. A handbook FAO Fisheries Technical Paper. No 362. Rome.

Ekanem, A.P., Eteng, S.U., Nwosu, F.M., \& Eyo, V.O. (2012). Comparative study of the growth and gonad development of Clarias gariepinus (Burchell 1822) fed diets with plant and animal-based ingredients in concrete tanks. Journal of Agricultural Science and Technology, p. 1203-1210.

Evans, R.P., Parrish, C.C., Brown, J.A., \& Davis, P.J. (1996). Biochemical composition of eggs from repeat and first-time spawning captive Atlantic halibut (Hippoglossus hippoglossus). Aquaculture. Aquaculture, 139, 139-149.

Eyo, V.O. \& Akanse, N.N. (2018). Comparative study on the condition factor, hematological and serum biochemical parameters of wild and hatchery collected broodfish of the African Catfish Heterobranchus longifilis (Valenciennes 1840). Asian Journal of Advances in Agricultural Research, 5(4), 1-8. https://doi.org/10.9734/AJAAR/2018/ 39238.

Eyo, V.O., Ekanem, A.P., Eni, E.G., Edet, A.P., \& Udo, J.U. (2013). Comparative study of growth perfor- 
mance, food utilization and survival of hatchery bred and wild-collected fingerlings of African Catfish Clarias gariepinus. Greener Journal of Oceanography and Marine Science, 1(1), 1-10.

Eyo, V.O., Ekanem, A.P., \& Jimmy, U.U. (2014). A comparative study of the gonado-somatic index (GSI) and gonad gross morphology of African Catfish (Clarias gariepinus) fed Unical aqua feed and coppens commercial feed. Croatian Journal of Fisheries, 72(2), 63-69. https://doi.org/10.14798/ 72.2.706.

FAO. (2017). Global aquaculture production (1950 2015). Country Profile Fact Sheets. 1 November 2017.

Heinimaa, S. \& Heinimaa, P. (2004). Effect of female egg size on egg quality and fecundity of the wild Atlantic salmon in the sub-arctic River Teno. Boreal Environment Research, 9, 55-62.

Hicks, T., Kopf, R.K., \& Humphries, P. (2015). Fecundity and egg quality of dusky flathead (Platycephalus fuscus) in East Gippsland, Victoria. Institute for Land Water and Society, Charles Sturt University. Report number 94. Prepared for the Recreational Fishing Grants Program, Fisheries Victoria.

Izquierdo, M.S., Fernandez-Palacios, H., \& Tacon, A.G.J. (2001). Effect of broodstock nutrition on reproductive performance of fish. Aquaculture, 197, 25-42.

Kamler, E. (2005). Parent-egg-progeny relationships in teleost fishes: An energetics perspective. Rev. Fish Biol. Fisher., 15, 399-421.

Kjørsvik, E., Hoehne-Reitan, K., \& Reitan, K.I. (2003). Egg and larval quality criteria as predictive measures for juvenile production in turbot (Scophthalmus maximus L.). Aquaculture, 227, 9-20.

Mayer, I., Shackey, S.E., \& Witthames, P.R. (1989). Aspects of reproductive biology of Bass,
Decentrarchus Labrax $L$, fecundity and pattern of oocyte development. Journal of Fish Biology, 3, 141-148.

Ojanguren, A.F., Reyes-Gavilan, F.G., \& Brana, F. (1996). Effects of egg size on offspring development and fitness in brown trout, Salmon trutta L. Aquaculture, 147, 9-20.

Opeh, P.B., Eyo, V.O., \& Udo, P.J. (2018). Effects of different inclusion levels of moringa oleifera leaf meal (MLM ) on the fecundity and gonadosomatic index (GSI) of the African Catfish Heterobranchus longifilis. Asian Journal of Advances in Agricultural Research, 6(1), 1-9. https://doi.org/10.9734/AJAAR/ 2018/39847.

Phleps, R.P. (2010). Recent advances in fish hatchery management. Soci. Bra. de Zoot., 39, 95-101.

Quiñones-arreola, M.F., Arcos-ortega, G.F., Gracialópez, V., Casillas-hernández, R., Weirich, C., Morris, T., \& Paz, L. (2015). Reproductive broodstock performance and egg quality of wildcaught and first-generation domesticated Seriola rivoliana reared under same culture conditions. Latin American Journal of Aquatic Research, 43(5), 953-962. https://doi.org/10.3856/vol43-issue5fulltext-15.

Shearer, K.D., Asgard, T., Andorsdottir, G., \& Aas, G.H. (1994). Whole body elemental and proximate composition of the Atlantic salmon (Salmo salar) during the life cycle. Journal of Fish Biology, 44, 785-797.

Watanabe, T. (1990). Effect of broodstock diets on reproduction of fish. Actes Colloq. IFREM ER, 9, 542-543.

World Bank. (2014). Press Release:Fish Farms to Produce Nearly Two Thirds of Global Food Fish Supply by 2030, Report. 